\title{
JUURNAL_RU
}

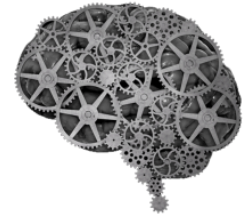

COMPANY GROUP "INTELLEKT"

\author{
Онищук Д.С. \\ МГУ им.М.В.Ломоносова \\ Москва, Россия
}

doi: 10.18411/lj2016-3-28

\section{История становления системы саморегулируемых организаций в Российской Федерации}

В рамках экономики России институт саморегулирования функционирует не так давно. Принимая во внимание плановый характер советской экономики, развитие механизмов саморегулирования осуществить было практически невозможно, а потому движение в этом направлении обозначилось лишь в начале 90-х годов 20 века.

Тем не менее, с уверенностью можно говорить о немалом количестве попыток внедрения института на протяжении практически всей российской истории, во многих случаях неосознанно, и, бесспорно, на практике, а не в форме законодательного оформления. Во время 1130-х годов в Древней Руси функционировали различные цеховые организации, у большинства из которых были собственная казна и управление. Более того, некоторые купеческие гильдии, например в Новгороде, обладали своим уставом, определенным сводом правил, который распространялся на всех членов гильдии, что по сути можно считать неким прообразом механизмов современных СРО.

Нужно заметить, что подобные системы цехов функционировали на протяжении долгого периода российской истории; однако во времена Петра I цеховые организации начинают разграничивать по профессиональному признаку, а управляющий орган - называть «управой». В 19 веке происходит 
формирование союзов, которое предполагало функционирование нескольких цехов в рамках одной структуры. Подобная схема осуществлялась для того, чтобы новоиспеченные союзы могли иметь больший вес при представительстве собственных интересов в городской управе. Рассматривая подобные нюансы взаимодействия негосударственных объединений с представителями власти, можно увидеть зарождение первых элементов саморегулирования. В целом, они проявляли себя довольно часто на протяжении развития политической системы российского государства, несомненно влияя и на процесс распределения некоторых полномочий внутри государства.

Для целей настоящей статьи, представляется целесообразным вспомнить и московскую биржу, которая была создана в 1870 году на фондовом рынке российской империи. Если рассматривать ее основные характеристики, вполне можно проследить параллели с функционирующими на сегодняшний день в России СРО. Позднее, уже в 20-м веке можно говорить о появлении на территории государства торгово-промышленных палат, которые имели возможность избирать третейских судей, а также создавать собственные нормы правил, то есть частично обладали функциями существующих сегодня СРО. Более того, уже на тот момент времени можно было увидеть первичные попытки лоббирования интересов подобных организаций путем выработки собственных заключений на некоторые законопроекты, которые имеют отношение к непосредственной деятельности различных представителей торговопромышленных палат в стране.

Несколько позднее, в период 20-х годов можно говорить о появлении еще одной цели функционирования таких организаций, а именно установлению различных внешнеэкономических связей на негосударственном уровне. В качестве примера можно привести создание Северо-Западная областной торговой палаты, полномочия которой заключались в регулировании торговли в России. 
Тем не менее, говорить о полном законодательном закреплении, а также оформление института в том качестве, которое мы наблюдаем на сегодняшний день, можно существенно позднее. В рамках отечественного законодательства СРО упоминается в Постановлении Правительства РФ от 28 апреля 1995 года №439 «О Программе Правительства Российской Федерации «Реформы и развитие российской экономики в 1995 - 1997 годах» ${ }^{1}$. Данный нормативный акт можно считать одним из первых, если говорить об официальном закреплении института в рамках нашего государства. В нем фиксируется передача саморегулируемым организациям определенной части полномочий по выработке новых стандартов, а также непосредственный контроль над должным исполнением уже функционирующих на определенный момент времени правил в сфере рынка ценных бумаг. Еще позднее, уже в 2000-м году институт упоминается в Постановлении Правительства №121 «О Федеральной программе государственной поддержки малого предпринимательства в Российской Федерации на 2000-2001 годы»². В этом случае, речь идет о разнообразных объединениях и союзах предпринимателей, с помощью которых предполагалось осуществление полноценного замещения механизмами саморегулирования государственного регулирования установленной части деятельности бизнеса.

Однако сразу говорить полноценном присутствии механизмов саморегулирования в рамках российской экономики на тот период времени не представляется возможным, учитывая разрозненность попыток и отсутствие системности в процессе их внедрения. Тем не менее, некий зародыш подобной системы был создан, в то время как мысли о его дальнейшем развитии витали в умах как государственных управленцев, так и в рамках предпринимательского сообщества.

Необходимо понимать, что в начале 2000-х годов взаимоотношения между властью и бизнесом были далеки от идеала, учитывая весь набор кризисных

\footnotetext{
${ }^{1}$ С3 РФ, 1995, №21, ст.1966

${ }^{2}$ С3 РФ, 2000, №8, ст.959
} 
явлений в экономике страны и намечавшийся переход к другой модели ее развития, была потребность в достаточно жестком контроле за деятельностью предпринимательского сообщества, и в то же время - в создании необходимых условий для обеспечения возможности ее быстрого и эффективного развития. Чрезвычайное давление на бизнес как со стороны потребителей, так и властей стало неким стимулом для окончательного формирования института саморегулирования. Процесс перехода к рыночным отношениям включал элементы государственного регулирования. Огромное количество различных видов предпринимательской и профессиональной деятельности контролировалось в рамках института лицензирования и некоторыми законодательными актами в соответствующих сферах. Бесспорно, с учетом подобного фона, многие предпринимательские структуры начинали сливаться в союзы, ассоциации и т.д. для целей лоббирования собственных интересов во взаимоотношениях с государством, а также для возможности функционирования в качестве более сильных и самостоятельных игроков на рынке. Так, в качестве примера одних из первопроходцев в сфере саморегулирования Российской Федерации можно назвать Союз фондовых бирж (1993г.), профессиональную организацию регистраторов, трансфер-агентов и депозитариев (ПАРТАД) (1994г.), Национальную ассоциацию участников фондового рынка (НАУФОР) (1994г.), все из которых и на сегодняшний день функционируют в статусе СРО.

Нужно отметить, что не только практически, но и в теоритической плоскости долгое время четкого определения феномена саморегулирования и СРО в России не наблюдалось. Не было ни общепринятой дефиниции понятий, ни понимания их места в экономической и политической системе страны. Поэтому логичным представляется появившееся у представителей властных и предпринимательских структур понимание жесткой необходимости разработки закона, который закрепил бы нормы действия механизмов саморегулирования в Российской Федерации. Более того, подобная мысль несколько раз была высказана Президентом РФ в своем послании Федеральному Собранию, а также 
поддержана Конституционным Судом России. Однако, нужно отметить, что в Государственной Думе РФ проект Федерального закона «О саморегулируемых организациях» находился в стадии разработки несколько лет, только в 2003 году прошло его первое чтение, в то время как принят он был уже в 2007 году. Бесспорно, назвать его безупречным было невозможно, тем не менее, наконецто появилась возможность говорить о наличии юридической основы деятельности саморегулируемых организаций в России. Этот закон и на данный момент принято считать базовым в сфере функционирования СРО в рамках нашего государства. Также нужно обратить внимание определенное нововведение в анализируемой области, а именно вступление в силу с января 2016 года Федерального закона «О саморегулируемых организациях в сфере финансового рынка и о внесении изменений в статьи 2 и 6 Федерального закона «О внесении изменений в отдельные законодательные акты Российской Федерации». Данный закон разработан с целью установления обособленного контроля за СРО на финансовых рынках.

Таким образом, с одной стороны, пройдя достаточно долгий путь становления, с другой, с точки зрения законодательного оформления достаточно молодой институт в России, саморегулирование играет непоследнюю роль в рамках функционирования сложившихся экономической и политической систем в рамках нашего государства. Более того, можно отметить наличие постоянных инициатив по совершенствованию теоритических и практических основ деятельности саморегулируемых организаций. 